\title{
Drug-related problems observed in a pharmaceutical care service, Belo Horizonte, Brazil
}

\author{
Yone de Almeida Nascimento ${ }^{2 *}$, Wânia da Silva Carvalho ${ }^{1}$, Francisco de Assis Acurcio ${ }^{1}$ \\ ${ }^{1}$ Faculty of Pharmacy, Federal University of Minas Gerais, ${ }^{2}$ Newton Paiva University Center
}

\begin{abstract}
This present observational, longitudinal, and non-concurrent study was developed with the purposes of evaluate the profile of patients attended by a pharmacotherapeutic follow-up service and describe the Drug-Related Problems (DRPs) found over there; determine the proportion of DRPs between the health problems presented by the studied population, classifying them and identifying the situations related with their appearance. The study was developed at the School Pharmacy of Newton Paiva University Center, Belo Horizonte, MG, during the period from 2001 November up to 2003 November. Ninety seven patients have been evaluated, the majority of female sex $(66.0 \%)$, with up to 8 years of scholarship $(45.4 \%)$, mean age of $56.7 \pm 13.0$ years; mean of $4 \pm 2$ diagnosed diseases; $7 \pm 6$ complaints and $4 \pm 2$ medications per patient. Nine hundred and twelve health problems have been identified: $56.5 \%$ uncontrolled. From the uncontrolled problems, $380(73.6 \%)$ were DRPs and between these, 81 (21.3\%) were risks for DRP. From the 97 followed-up patients, 89 (91.7\%) have presented at least one DRP during the follow-up. The more frequent DRPs were related to effectiveness $(53.2 \%)$, to necessity $(25.2 \%)$ and to safety $(21.6 \%)$. A great number of uncontrolled problems was observed, as well as the possibility to resolve them by means of pharmaceutical care, indicating so the resolutive potential of this practice.
\end{abstract}

Uniterms: Pharmaceutical care. Pharmacotherapeutic follow-up. Drug Related Problem (DRP).

O presente estudo observacional, longitudinal, não concorrente teve por objetivos avaliar o perfil dos pacientes atendidos por um serviço de acompanhamento farmacoterapêutico e descrever os 'problemas relacionados com medicamento' (PRM) encontrados; determinar a proporção de PRM dentre os problemas de saúde apresentados pela população estudada, classificá-los e identificar situações relacionadas com seu surgimento. O estudo foi realizado na Farmácia Escola do Centro Universitário Newton Paiva, em Belo Horizonte, MG, durante o período de novembro de 2001 a novembro de 2003. Foram avaliados 97 pacientes, maioria mulheres $(66,0 \%)$, com até 8 anos de escolaridade $(45,4 \%)$, média de idade de $56,7 \pm$ 13,0 anos; média de $4 \pm 2$ doenças com diagnóstico; $7 \pm 6$ queixas e $4 \pm 2$ medicamentos por paciente. Foram identificados 912 problemas de saúde: $56,5 \%$ não controlados. Dos problemas não controlados, 380 (73,6\%) eram PRM e desses 81 (21,3\%) eram riscos de PRM. Dos 97 pacientes acompanhados 89 $(91,7 \%)$ apresentaram pelo menos um PRM durante o acompanhamento. Os PRMs mais freqüentes foram relacionados à efetividade $(53,2 \%)$, à necessidade $(25,2 \%)$ e à segurança $(21,6 \%)$. Observou-se grande número de problemas não controlados e a possibilidade de resolvê-los por meio da atenção farmacêutica, demonstrando o potencial resolutivo dessa prática.

Unitermos: Atenção farmacêutica. Acompanhamento farmacoterapêutico. Problemas Relacionados com Medicamentos (PRM).

\section{INTRODUCTION}

The pharmaceutical care (PC) is considered as a change in the profession conception and has arisen at the

*Correspondence: Y. A. Nascimento. Centro Universitário Newton Paiva. Av. Silva Lobo, 1730 - 30.460-000 - Nova Granada - Belo Horizonte - MG, Brazil. E-mail: yone_almeida@hotmail.com beginning of 90's in the United States. With the intention to adapt the concept initially proposed by Heppler \& Strand (1990) to national reality, it was elaborated the Brazilian Consensus of Pharmaceutical Care (Consenso Brasileiro de Atenção Farmacêutica), which defines the pharmaceutical care as a conjunction of activities in which the pharmacist interacts directly with patients; between these 
activities are the dispensation, the health education, the pharmaceutical orientation, and the pharmacotherapeutic follow-up (Pan American Health Organization; 2002).

The pharmaceutical care has arisen and is spreading itself as a result of numberless works showing an important increase of both, morbimortality and health costs, which is due to the use of medicine. The adverse reactions have been considered the fourth death cause at United States, losing only for cardiovascular diseases, cancer, and cerebrovascular accident (Johnson, Bootman; 1995). Ernst, Grizzle (2001) have verified also, in that same country, an annual cost of 177.4 billion dollars related with this kind of morbimortality in outpatients.

As referred by Strand (1990), the main purpose for all healthcare professionals is to improve the patients' quality of life, being that every professional contributes with his/her specific practice. This way, pharmaceutical care can contribute to assure the outcome of pharmacological therapy, once it presupposes three main responsibilities in the clinical context: 1) to meet patients' necessities respecting to pharmacotherapy, that is, to assure that patients requiring a medication utilize it, that the used pharmacotherapy is the most effective available one, the most safe possible one, and that it can be used as indicated; 2) to identify, resolve, or prevent any problem related to pharmacotherapy, which could interfere with the above described pharmacotherapeutic necessities; 3 ) to assure that treatment goals and optimal results are reached. Therefore, during his/her practice, the pharmacist shall be able to determine if the necessities described by patients are not being met and, in this case, translate them into drug related problems, proposing then interventions that are able to resolve these necessities (Cipolle et al., 2004; Consenso, 1999; Espejo et al., 2002).

This work had as purposes to evaluate the profile of patients attended by a pharmacotherapeutic follow-up service, and describe the drug related problems found in this group of patients, and reported by the pharmacists developing the follow-up; to determine the proportion of drug related problems (DRPs) between the health problems presented by the studied population, classify the DRPs according to categories professed by the Second Consensus of Granada respecting Drug Related Problems (2002), and identify the situations leading to appearance of a DRP.

\section{POPULATION AND METHODS}

This is an observational, longitudinal, and non-concurrent study developed at School Pharmacy of Newton Paiva University Center (FECUNP), Belo Horizonte, in the period between 2001 November and 2003 November.
It was a pharmacy placed in a middle class neighborhood, beside the Faculty, and also close to a great community of low acquisitive power, named Morro das Pedras. This way, the pharmacy possesses three different kinds of public: students, University Center employees and teachers, neighborhood dwellers, and residents of the referred community. The patients candidate to pharmacotherapeutic follow-up service were, in their majority, dwellers of Morro das Pedras, but neighborhood patients and university center employees have also been followed-up. The offered service was unpaid.

All patients submitted to pharmacotherapeutic follow-up, who entered in the service up to 2003 May and agreed to participate were considered eligible for the study. It was developed an initial anamnesis and the obtained data were recorded into a follow-up card.

Only follow-up cards from patients who agreed to participate and signed an informed consent were included; the patients that did not agree to participate did not suffer any disservice in their follow-up, as well. The data have been presented aggregately, without the identification of any patient. The work has been submitted to Institutional Review Board/Independent Ethics Committee of the Federal University of Minas Gerais (UFMG), being opportunely approved.

In the service, the real problems related to pharmacological therapy (DRP) and the other health problems (HP) were identified, classified and ordered according the priority for resolution. The risks for DRP, in the studied population, have also been identified. For every health problem identified, pertinent goals and interventions have been drawn. New problems reported by participants were being recorded, classified and resolved continuously (Universidad de Granada, 1999; Cipolle et al., 2004).

For this study elaboration, data referring to health problems and complaints reported by patients were collected, as well as data referring to utilized medications. In the first case, all the records done in the follow-up cards up to 2003 May were used; yet in the second case, only the records of the initial anamnesis were considered. A codification of health problems and complaints was developed from the CID 10 (WHO, 2003). For the classification of medications it was used the ATC system (Anatomical Therapeutic Chemical Classification System) (http://www. whocc.no/atcddd).

For the identification of found problems, the data recorded in the follow-up cards were analyzed and recorded in a data collection card. They have been classified as: DRP; Health problem unrelated to medication use and uncontrolled (HP); Controlled health problem; Informed health problem (defined as a vaguely informed problem, 
TABLE I - Classification of 'Drug Related Problems' (DRP)

\begin{tabular}{ll}
\hline Necessity & Problem \\
\hline Necessity & DRP 1: The patient suffers from a health problem as a result of not taking the medicine that he needs. \\
& DRP 2: The patient suffers from a health problem as a result of taking a medicine that he does not need. \\
Effectiveness & DRP 3: The patient has a health problem resulting from a non-quantitative ineffectiveness of a medicine. \\
& DRP 4: The patient has a health problem resulting from a quantitative ineffectiveness of a medicine. \\
Safety & DRP 5: The patient suffers from a health problem as a consequence of a non-quantitative safety problem of a \\
& medicine. \\
& DRP 6: The patient suffers from a health problem as a consequence of a quantitative safety problem of a medicine.
\end{tabular}
Source: SEGUNDO CONSENSO DE GRANADA SOBRE PRM, 2002

without the detailing necessary for adoption of interventions); Health problem under evaluation (defined as a problem for which an intervention had already occurred, being necessary to wait for the respective result).

In this work, the definition and classification of DRP professed by the Second Consensus of Granada respecting Drug Related Problems (2002) (Table I) have been adopted.

A descriptive data analysis has been developed, in a procedure that has included the determination of proportion of drug related problems (DRP) between the health problems presented by the studied population, in a general way and according to professed categories. It has included also frequencies distribution, central trend measures and variability measures.

\section{RESULTS AND DISCUSSION}

Ninety seven patients were analyzed, being the majority of them women $(66.0 \%)$, married (52.6\%), with up to 8 years of scholarship (45.4\%) and do not exerting any professional activity $(55.7 \%)$. The mean age of participants was $56.7 \pm 13.0$ years and the median 60 years (range 24-92 years).

Women presented the worst self-referred functional and health statuses, higher frequency of reports related to depressive symptoms and hospitalization history. In 1997 in the United States, about $70 \%$ of hospitalized patients were of female sex. This way, they have also searched more frequently for health services, including the PC services, varying between $59 \%$ and $76 \%$ of attended population (Leanne, 1998; Rosenfeld, 2003; Cipolle et al., 2004).

About $60 \%$ of studied patients presented up to eight years of scholarship. This is a characteristic that could negatively affect the formulation and comprehension of concepts of self care in health, besides to exert some influence on the necessary time as well as the employed vocabulary, for execution of educative actions.
The expressive number of individuals aged above 50 years could be explained by the form of individuals gathering applied in this study, which initially has been developed by means of activities of education in health. This is a public more seized by chronic diseases; therefore, they are more worried about health, and more commonly look for activities subsidizing self care. The mean age found was compatible with the results of other PC services in the United States (58 years) (Leanne, 1998; Cipolle et al., 2004).

Ninety six (99\%) out of all followed-up patients reported, at least, one disease with a diagnosis done by a physician. Three hundred ninety six diseases have been reported, with an average of $4 \pm 2$ diseases per patient, median of 4 diseases (range $=0$ to 11). The results of this study are similar to those obtained by Cipolle et al. (2004) that, in a study developed with 20761 patients in the United States, have found an average of $3 \pm 2$ diseases in patients younger than 65 years, and $5 \pm 2$ diseases in those older than 65 years.

As expected, the more mentioned diseases corresponded to the chronic ones, common in the age range more frequent between the participants of this study, such as arterial hypertension $(19.7 \% ; 78)$, disturbance in the lipoprotein metabolism $(6.3 \% ; 25)$ and diabetes mellitus $(4.8 \% ; 19)$.

During the follow-up, 96 patients (99\%) have referred, at least, one complaint. The observed average was of $7 \pm 6$ complaints and the median was of 5 complaints (range $=0$ to 32 ). The complaints were defined as signals, symptoms or diseases without medical diagnosis, reported by the patient or observed by the pharmacist. As a whole, 674 complaints have been reported.

The algic complaints corresponded to $30.4 \%$ of all reported/observed complaints in this study, comprehending the complaints in the osteomuscular apparatus, the headaches and the pains non-classified in other parts. Carvalho (1999) affirms that the pain has been less valorized as a 
symptom or disease, during the formation of health professionals. Such a fact reinforces the importance of pharmacists adequately trained for pain handling, who know exactly when make use of therapeutic strategies, such as OTC medications, and what is the suitable moment to forward the patient to a physician, for more detailed evaluation; contributing so to improve the quality of care provided to patients.

The other more reported complaints were 'fatigue/ malaise' $(5.0 \%, 34)$, 'intestinal constipation' $(4.3 \%, 29)$; 'sleeping disturbances' $(4.3 \%, 29)$ and 'dizziness and vertigo' $(3.9 \%, 26)$.

It is even appropriate to emphasize that 20 patients $(20.6 \%)$ presented complaints related to 'emotional status or behavior'; yet $33 \%$ of patients reported 'sleeping alterations'. Such data look to be coherent with those obtained by Szwarcwald (2004), in a published study about Brazilians perception respecting their own health, which verified that $25 \%$ of individuals reported a severe or very severe grade of disturbance respecting the state of mind (sadness or depression, worry or anxiety) and $18 \%$ presented sleeping problems. These results could be evaluated based on the current social context, in which situations of unsafety, criminality, unemployment and inequality are present.
All the followed-up patients reported the use of, at least, one medication, totalizing 416 medications. The observed average of utilization was $4 \pm 2$ medications, median of $4($ range $=1$ to 13$)$. Out of this total, $338(81.3 \%)$ were prescribed, $60(14.4 \%)$ were not prescribed and for 18 medications $(4.3 \%)$ this information was not reported. The data found in this study were compatible with other published ones, being that Cipolle et al. (2004) have verified that patients younger than 65 years were making use of an average of 5 medications, while those older than 65 years reported an average of 7 medications. Yet Durán (1999) has found an average of 6.1 medications per patient during six months of follow-up.

In Brazil, studies developed during the pharmacotherapeutic follow-up of hypertensive patients, have verified averages of $8.5 \pm 4$ medications per patient (LyraJúnior et al, 2007) and $5.4+1.08$ medications per patient (Souza et al, 2007).

The more utilized medications were those necessary for the treatment of the most reported diseases, such as the medications acting on the cardiovascular system, corresponding to 145 (34.9\%) mentions. Following, are described the utilized medications, classified according the ATC system (Table II).

TABLE II - Distribution of medications used by patients followed-up at FECUNP, from 2001 to 2003 - First and second level of ATC classification

\begin{tabular}{lcc}
\hline Medications & Frequency & Percentage \\
\hline Cardiovascular system & $\mathbf{1 4 5}$ & $\mathbf{3 4 . 9 \%}$ \\
Diuretics & 44 & $10.6 \%$ \\
Acting over the renin-angiotensin system & 31 & $7.5 \%$ \\
Beta-blockers and associations & 21 & $5.0 \%$ \\
Calcium channel blockers and associations & 21 & $5.0 \%$ \\
Central nervous system & $\mathbf{8 6}$ & $\mathbf{2 0 . 7 \%}$ \\
Psycholeptics ${ }^{1}$ & 28 & $6.7 \%$ \\
Analgesics & 26 & $6.2 \%$ \\
Psychoanaleptics & 20 & $4.8 \%$ \\
Gastrointestinal tract and metabolism & $\mathbf{1 6 . 8 \%}$ \\
Used in diabetes & $\mathbf{7 0}$ & $6.2 \%$ \\
Antacids and other for ulcer and flatulence & 26 & $4.6 \%$ \\
Musculoskeletal system & 19 & $\mathbf{6 . 5 \%}$ \\
Anti-inflammatory and antirheumatic & $\mathbf{2 7}$ & $3.1 \%$ \\
Blood and hematopoietic organs & 13 & $\mathbf{5 . 0 \%}$ \\
Antithrombotics & $\mathbf{2 1}$ & $4.6 \%$ \\
Genitourinary tract & 19 & $\mathbf{3 . 8 \%}$ \\
Sexual/modulator hormones & $\mathbf{1 6}$ & $3.5 \%$ \\
Hormones & 15 & $\mathbf{3 . 8 \%}$ \\
Thyroid treatment & $\mathbf{1 6}$ & $3.4 \%$ \\
Other & 14 & $\mathbf{8 . 5 \%}$ \\
\hline TOTAL & $\mathbf{3 5}$ & $\mathbf{1 0 0 , 0 \%}$ \\
\hline
\end{tabular}

${ }^{1}: 5.8 \%$ corresponding to anxiolytics; ${ }^{2}: 3.6 \%$ corresponding to anti-depressives. 


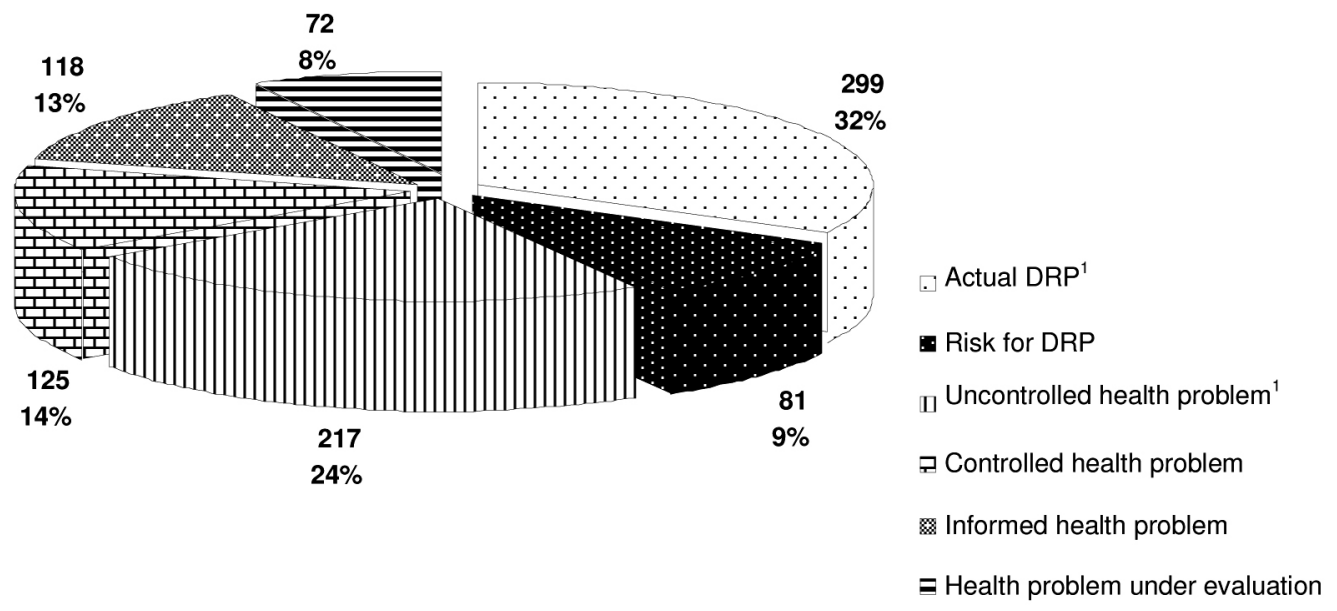

FIGURE 1 - Distribution of health problems, per category, presented by patients followed-up at FECUNP from 2001 to 2003. Note 1: Uncontrolled problems.

The medications acting on the central nervous system corresponded to the second class of more mentioned medications $(20.7 \%)$, which looks to point out their use with the purpose of relief symptoms/signals related to emotional status as well as sleeping disturbances and syndromes of cephalalgia and migraine, which if summed, correspond to the third more frequent group of complaints. Considering the previous discussion about multi-causality of diseases, it becomes important to evaluate the role of the medicalization of such disturbances, as well as to work with the purpose to propose changes that are shown more effective and/or safe for the treatment of such disturbances.

912 problems in the 97 participant patients have been identified, being 516 (56.5\%) of them uncontrolled, requiring an intervention from the pharmacist. These problems included the health problems non-related to the use of medications, which presented themselves as uncontrolled; and the real DRPs as well. Following, the frequency distribution of problems according to categories professed in this study (Figure 1).

Yet, Table III presents a descriptive analysis of found problems. It is possible to perceive that the average of health problems reported by individuals was similar to the average of both, uncontrolled and DRP-type problems found by pharmacists during the pharmacotherapeutic follow-up.

From the found problems, $380(73.6 \%)$ were DRPs and between these ones, 81 (21.3\%) were risks for DRP, that is, problems that had not appeared yet, but that had a good chance to occur.

Out of the 97 followed-up patients, 89 (91.7\%) presented, at least, one DRP during the follow-up, 18 (18.6\%) presented one DRP, 11 (11.3\%) two DRPs, 15 (15.5\%) three DRPs, 8 (8.2\%) four DRPs, $11(11.3 \%)$ five DRPs, $9(9.3 \%)$ six DRPs, and $17(17.5 \%)$ patients presented more than six DRPs. It is useful to emphasize that out of these last 17 patients, three presented twelve DRP-type problems during the follow-up. The average of DRPs was of 4, median of 3, varying from 0 to 12 DRPs per patient.

Cipolle et al. (2004) have reported the presence, only at the first follow-up, of at least one DRP in $42 \%$ of followed-up patients, and that one out of every five patients presented multiple DRPs, in a total of 5136 followed-up patients. Rossinholi (2002) has identified DRPs in 54\% of 35 patients enrolled into a pilot-project for the implantation of pharmaceutical care in Curitiba. Yet, Durán (1999)

TABLE III - Descriptive analysis of problems observed at FECUNP, 2001 to 2003

\begin{tabular}{lcccc}
\hline & $\begin{array}{c}\text { Mean } \pm \text { Standard } \\
\text { Deviation }\end{array}$ & Median & \multicolumn{2}{c}{ Range } \\
\cline { 3 - 5 } & $9 \pm 5$ & 8 & Minimum & Maximum \\
\hline Health problems $(\mathrm{n}=912)$ & $5 \pm 3$ & 5 & 3 & 23 \\
Uncontrolled problems $(\mathrm{n}=516)$ & $4 \pm 3$ & 3 & 0 & 16 \\
DRPs (n=380) & $3 \pm 2$ & 3 & 0 & 12 \\
Actual DRPs $(\mathrm{n}=299)$ & & & 1 & 10 \\
\hline
\end{tabular}


encountered 48 DRPs in 35 patients, corresponding to 1.8 DRPs per patient; he verified yet that $74.3 \%$ of patients presented, at least, one DRP. It is possible to notice a higher average of DRPs in that study as compared with other works, but it is convenient to highlight that these DRPs were continuously identified and recorded along all the follow-up, besides to be not restricted to specific disturbances, as the results obtained in other publications of this same area (Cranor \& Christensen, 2003 a,b,c; Hernández-Ronquillo et al., 2003).

The professional who develops the PC should be able to translate the patients' necessities respecting to pharmacotherapy that are not being attended in DRP; and from that point on, delineate strategies for their resolution. Therein, it is very interesting the work developed by Law (2003), which divides the process of use of medications into nine steps, evaluating then the opinion of physicians, pharmacists, and patients respecting how these steps have been conducted. Only $10 \%$ of patients have identified problems in the described steps, however, $30 \%$ of these patients have done comments respecting the cost of prescriptions, the adequacy of therapy, the access to caretakers, and the convenience of treatment. These comments indicate that there are important issues being neglected in the process of use of medications, and these issues could be DRP generators. The professional is in charge of develop their listening, comprehend such necessities and, face to a negative clinical result or its imminence, intervene in order to resolve or prevent its occurrence. So, the definition of the pharmacist's role in the identification, resolution, and prevention of DRPs situates clearly his/her function in the context of global attention provided to patient.
In this study, the more frequent problems were those related to effectiveness of proposed treatments (Table IV). This is an important problem of public health, once resources are being spent for the treatment/control of diseases, which are not being adequately controlled. Ernst \& Grizzle (2001) have estimated an average cost of 977 dollars for the treatment of therapeutic failures, and of 1,105 dollars for the treatment of a new health problem resulting from the wrong use of medications. It is convenient to emphasize yet that these problems configure themselves as an important cause of morbimortality, besides to negatively impact the individuals' quality of life. The identification of fortuitous cases of non-effectiveness, the search for their possible causes, and their final resolution assume then an essential role for the patients' care. This is an important change of paradigm, once the pharmacists, traditionally, have focalized their actuation on problems related to medications safety and, despite the obvious importance of such problems, those linked to the lack of effectiveness should also be cautiously assessed (Cipolle et al., 1998).

Even, the main problem identified was the lack of effectiveness of treatments for disturbances in the cardiovascular system, corresponding to $13.8 \%(n=71)$ of all reports. Considering that blood hypertension was the most frequent problem, it is appropriate to emphasize the importance of constant monitoring of patients under this condition. The fast identification of patients who are not obtaining the desired effect with the professed therapeutic strategy allows a readdressing of this patient for the health service, and could contribute for a more effective control of the clinical picture and, possibly, contribute also for the decrease of morbimortality related to cardiovascular

TABLE IV - Distribution of health problems, per category, presented by patients followed-up at FECUNP from 2001 to 2003

\begin{tabular}{lccccc}
\hline Diseases, disturbances and/or & \multicolumn{3}{c}{ Drug Related Problems } & Uncontrolled & TOTAL \\
signals and symptoms & Necessity & Effectiveness & Safety & Health Problem & \\
\cline { 2 - 5 } Circulatory apparatus & $20(3.9 \%)$ & $71(13.8 \%)$ & $7(1.4 \%)$ & $25(4.9 \%)$ & 123 \\
Osteomuscular system & $8(1.5 \%)$ & $30(5.8 \%)$ & $3(0.6 \%)$ & $23(4.4 \%)$ & 64 \\
Endocrines, nutritionals & $6(1.2 \%)$ & $25(4.9 \%)$ & $9(1.7 \%)$ & $34(6.6 \%)$ & 74 \\
Digestive apparatus $_{\text {Mental and behavioral }}^{1}$ & $3(0.6 \%)$ & $14(2.7 \%)$ & $14(2.7 \%)$ & $33(6.4 \%)$ & 64 \\
Nervous system $_{\text {Genitourinary apparatus }}^{10(1.9 \%)}$ & $7(1.4 \%)$ & $9(1.7 \%)$ & $10(1.9 \%)$ & 36 \\
Infectious diseases $^{2}$ & $1(0.2 \%)$ & $16(3.1 \%)$ & $1(0.2 \%)$ & $19(3.7 \%)$ & 37 \\
Skin and subcutaneous tissues & $5(1.0 \%)$ & $3(0.6 \%)$ & $5(1.0 \%)$ & $11(2.1 \%)$ & 24 \\
Other & $8(1.5 \%)$ & $3(0.6 \%)$ & $0(0.0 \%)$ & $0(0.0 \%)$ & 11 \\
Total & $0(0.0 \%)$ & $1(0.2 \%)$ & $2(0.4 \%)$ & $6(1.2 \%)$ & 9 \\
\hline
\end{tabular}

${ }^{1}$ : related to cognition, perception, emotional state and behavior; ${ }^{2}$ : Includes parasitic 
TABLE V - Main identified causes for DRP found at FECUNP from 2001 to 2003

\begin{tabular}{lcccc}
\hline CAUSE & \multicolumn{2}{c}{ Total of DRP } & \multicolumn{2}{c}{ Risk for DRP } \\
\cline { 2 - 5 } & Frequency & Percentage & Frequency & Percentage \\
\hline Non-utilization of medication & 96 & $25.3 \%$ & 34 & $43.3 \%$ \\
Prescription in lower dose $^{\text {Unidentified cause }}{ }^{1}$ & 79 & $20.8 \%$ & 3 & $3.7 \%$ \\
Refractoriness $^{\text {Non-prescription of required medications }}$ & 73 & $19.2 \%$ & 21 & $14.8 \%$ \\
Use of medication different than prescribed or & 35 & $9.2 \%$ & 0 & 0 \\
inadequate use & 35 & $9.2 \%$ & 2 & $2.5 \%$ \\
Interaction & 19 & $5.0 \%$ & 4 & $4.9 \%$ \\
Lacking access to medications & 18 & $4.7 \%$ & 9 & $11.1 \%$ \\
Prescription in higher dose & 18 & $4.7 \%$ & 7 & $8.6 \%$ \\
Ignored & 6 & $1.6 \%$ & 0 & 0 \\
Total & 1 & $0.3 \%$ & 0 & 0 \\
\hline R & $\mathbf{3 8 0}$ & $\mathbf{1 0 0 . 0 \%}$ & $\mathbf{8 1}$ & $\mathbf{1 0 0 . 0 \%}$ \\
\hline
\end{tabular}

${ }^{1}$ : Referred to cases of adverse reactions with undefined cause $(n=61)$ and to cases of DRP 2, due to the use of unnecessary medications $(\mathrm{n}=12)$.

events. Considering the problem magnitude (about $27 \%$ of the obits in Brazil, reaching 37\%, when excluded the barely defined causes and violence cases), it is a belief that the involvement of all health professionals in the identification and control of this disturbance and its consequences would exert a great impact all over the country public health (Sociedade Brasileira de Hipertensão Arterial, 2006).

In this study, the non-utilization of medications was the main cause of DRPs. Table V presents a description of the causes of actual DRPs and risks for DRPs found in this study. For some patients, the use of medications implies in a problem that is major than the illness itself, what contributes for a high rate of treatment abandonment, mainly for chronic diseases requiring a treatment for indefinite time (Cipolle et al., 1998; Grupo de trabajo sobre incumplimento del Hospital Geriátrico Virgen del Valle; 1991; Hernández-Ronquillo et al., 2003).

The non-utilization of medication on the part of patients, that is, the non-adherence, is a situation with high potential for generation of DRPs, which could be effectively worked by pharmacists at the basic attention level, by means of many interventions that are varied and broadly discussed in the literature, showing one more possibility of intervention of this professional in the sense of optimizing the results of pharmacologic therapy.

Respecting to uncontrolled health problems that are not related to medications, which corresponded in this study to $42.1 \%$ of all problems, it is appropriate to discuss the role of non-pharmacologic treatments, based on lifestyle modifications and indicated as main or supple- mentary measure to pharmacologic treatments for several disturbances. In this sense, the educational strategies for self-care help to improve the understanding of diseases, proposed treatments and preventive strategies; contributing also for the correction of concepts and mistaken beliefs. In this way, they enable individuals to decision-making respecting their own health, contributing to increase the adhesion to treatments and favoring the control of diseases (Barron-Rivera et al., 1998; Bettencourt et al., 2002; Norris et al., 2002).

When a health professional discuss with his/her patients respecting risks decrease, diseases treatment and medications use, there is a higher probability for patients to be changing their inadequate habits, participating in selections, and taking their medications correctly. Considering the potential that routine advising has for the improvement of people's and general public health, it is questionable why this practice is not more diffused (Center for the Advancement of Health, 2001).

However, it is necessary to emphasize that, as referred by Czeresnia \& Freitas (2003), the health promotion could be associated to preventive measures, respecting the physical environment and lifestyles, that is, issues that are under the individual control. But it is also associated to more complex issues that are out of individual's control, and to achieve health for everybody it is necessary to decrease inequalities, to increase the preventive efforts and the people's capacity to confront their own health problems. Therefore, the alterations in lifestyle could not be viewed as the single aspect for the health promotion, 
being risky to attribute only to the patient, all responsibility for his/her own health.

Even, respecting to detected problem, $13.2 \%$ of all reports corresponded to minor nuisances/situations that could be resolved by the pharmacist, by means of indication of OTC medicines; between them, some disturbances of gastrointestinal tract (constipation, nauseas, dyspepsia, pyrosis, and flatulence), sleeping disturbances, parasitosis e mycoses, as well as dermatological disturbances.

Nimmo (1999) affirms that the OTC medicines represent $60 \%$ of all medications sold within United States, which increases the pharmacist's responsibility in the indication, dispensation, and using follow-up of these medications. This way, the indication of medications, provided they are within their ambit of actuation, could be a useful intervention in the care process.

\section{CONCLUSIONS AND RECOMMENDATIONS}

In this study, it was found a population with sociodemographic characteristics that are similar to those of other studies population. It was possible to notice that the more mentioned diseases were the chronic diseases that are common in this age range, and the most mentioned medications represented the most utilized therapeutic alternatives to treat such diseases. It is important to emphasize that the most reported diseases corresponded to about $60 \%$ of all diseases mentioned by patients, facilitating so the training of professionals for the practice of pharmaceutical care.

The algic complaints, in conjunction with the state of mind and sleeping disturbances, point out the necessity to visualize the health-disease process through a more embracing mode, understanding health as the expression of quality of life. Under this perspective, the care approach extrapolates the curative dimension, being necessary to look for an integral and holistic focusing.

It is also necessary to mention that the alteration in lifestyle should be viewed as an important aspect for health promotion and the development of self-care abilities, a way to enable people to confront their own health proble$\mathrm{ms}$. In this sense, it is important to highlight the role performed by the pharmacist who proposes himself to develop the pharmaceutical care, mainly the pharmacotherapeutic follow-up. As a health educator, this professional could contribute for the adoption of more healthy life habits, which could impact on the appearance and/or evolution of several chronic diseases in a decisive way, justifying so the implementation of this practice in the country.

It is possible to perceive also a great number of uncontrolled health problems, between them the DRPs, whi- ch require the intervention of a professional; mainly the problems related to effectiveness of proposed medicines.

Several of these problems could be resolved by means of measures to be adopted by the pharmacists disposing themselves to work in the context of pharmaceutical care practice, as for instance, the introduction of non-pharmacological measures, the implantation of strategies to increase the adhesion to pharmacologic and non-pharmacologic treatments, the education about the correct use of medications, the health education, the indication of OTC medications and, as appropriate, the patients' forwarding to be evaluated by other health professionals; demonstrating so the usefulness and resolutive potential of this practice.

The majority of problems verified with the use of medicines are not inherent to it, but to the form in which medicines are prescribed, dispensed and used, justifying the necessity of a reorientation for the pharmaceutical profession; in other words, it is necessary a change of paradigm, with the pharmaceutical professional leaving the position of a mere 'medicine provider', to become a 'service provider' having the pharmaceutical care included among his responsibilities, as a service to be provided to public.

In this context, the pharmaceutical care is placed as an important strategy for the resolution of a serious problem of public health, the morbimortality related to the use of medicines; which on the other hand, exerts an important impact on the resources addressed to healthcare and on the individuals' quality of life, as well.

\section{REFERENCES}

BARRON-RIVERA, A.J.; TORREBLANCA, F.L; SÁNCHEZCASANOVA, L.I; BELTRAN, M.M. Efecto de una intervención educativa en la calidad de vida del paciente hipertenso. Salud Pública Méx., v.40, n.6, p.503-509, 1998.

BETTENCOURT, A.R.C. ; OLIVEIRA, MA; FERNANDES, ALG; BOGOSSIAN, M. Educação de pacientes com asma: atuação do enfermeiro. J. Pneumol., v.28, n.4, p.193-200, 2002.

BRASIL. Ministério da Saúde. Saúde Brasil, 2004: uma análise da situação de saúde. Brasília, 2004. 350 p.

CARVALHO, M. M. Dor: um estudo multidisciplinar. São Paulo: Summus, 1999. 341 p.

CENTER FOR THE ADVANCEMENT OF HEALTH. The integration of health behavior counseling into routine medical care. Rev. Panam. Salud Pública., v.9, n.6, p.413420, 2001. 
CIPOLLE, R.J.; STRAND, L. M.; MORLEY, P. C. Pharmaceutical Care Practice: The clinician's guide. New York: McGraw-Hill, 2004. 394 p.

CONSENSO de Granada sobre problemas relacionados com medicamentos. Pharm. Care Esp., v.1, n.1, p.107-112, 1999.

COSTA, S.; SANTOS, C.; MADEIRA, A., SANTOS, M.R.; SANTOS, R. Utilização de duas classificações diferentes de problemas relacionados com medicamentos em farmácias de oficina: a experiência portuguesa. Seguim. Farmacoter., v.2, n.4, p.267-285, 2004.

CZERESNIA, D.; FREITAS, C. M. Promoção da saúde: conceitos, reflexões, tendências. Rio de Janeiro: Fiocruz, 2003. 174 p.

CRANOR, C.W., CHRISTENSEN, D.B. The Asheville Project: Short-term outcomes of a community pharmacy diabetes care program. J. Am. Pharm. Assoc., v.43, n.2, p.149-159, 2003a.

CRANOR, C.W., CHRISTENSEN, D.B. The Asheville Project: factors associated with outcomes of a community pharmacy diabetes care program. J. Am. Pharm. Assoc., v.43, n.2, p. 173-184, 2003b.

CRANOR, C.W., CHRISTENSEN, D.B. The Asheville Project: Long-term clinical and economic outcomes of a community pharmacy diabetes care program. J. Am. Pharm. Assoc., v.43, n.2, p.160-171, 2003c.

DURÁN, I.; ROMERO, F.M.; FAUS, M.J. Problemas relacionados con medicamentos resueltos en una farmacia comunitaria. Pharm. Care Esp., v.1, n.1, p.11-19, 1999.

ERNST, F.R.; GRIZZLE, A.J. Drug-related morbidity and mortality: updating the cost-of-illness model. J. Am. Pharm. Assoc., v.41, n.2, p.192-199, 2001.

ESPEJO, J., LLIMÓS, F.F.; MACHUCA, M.J.F. Problemas relacionados con medicamentos: definición y propuesta de inclusión en la clasificación internacional de atención primaria (CIAP) de la WONCA. Pharm Care Esp., v.2, n.4, p.122-127, 2002.

GRUPO DE TRABAJO SOBRE INCUMPLIMENTO DEL HOSPITAL GERIÁTRICO VIRGEN DEL VALLE. Incumplimiento terapéutico en los ancianos. Med. Clin., v.100, n.19, p.736-740, 1991.
HEPPLER, C.D.; STRAND, L.M. Opportunites and responsabilities in pharmaceutical care. Am. J. Hosp. Pharm., v.47, n.3, p.543-554, 1990.

HERNÁNDEZ-RONQUILLO, L.; TÉLLEZ-ZENTENO, J.F; GARDUNO-ESPINOSA, J; GONZÁLEZ-ACEVEZ, E. Factors associated with therapy noncompliance in type-2 diabetes patients. Salud Pública Méx., v.45, n.3, p.101-197, 2003.

JOHNSON, J.A.; BOOTMAN, J.L. Drug-related morbidity and mortality: a cost-of-illness model. Arch. Intern. Med., v.155, n.18, p.1949-1956, 1995.

LAW, A.V; RAY, M.D.; KNAPP, K.K.; BALESH, J.K. Unmet needs in the medication use process: perceptions of physicians, pharmacists and patient. J. Am. Pharm. Assoc., v.43, n.3, p.394-402, 2003.

LEANNE, L.P. Effects of a pharmaceutical care intervention in primary care ambulatory settings among Medicaid population. J. Pharm. Care, v.2, p.1-9, 1998.

LIMA-COSTA, M.F. Epidemiologia do envelhecimento no Brasil. In: ROUQUAYROL, M.Z; FILHO, N.A. Epidemiologia e saúde. 6 ed. Rio de Janeiro: Medsi, 2003. cap. 16, p. 499-513.

LYRA-JÚNIOR, D. P.; ROCHA, C. E.; ABRIATA, J. P.; GIMENES, F. R.E.; GONZALEZ, M. M.; PELÁ, I. R. Influence of Pharmaceutical Care intervention and communication skills on the improvement of pharmacotherapeutic outcomes with elderly Brazilian outpatients. Patient Educ. Couns., v.68, n.2, p.186-192, 2007.

NASCIMENTO, Y.A. Avaliação de resultados de um serviço de atenção farmacêutica em Belo Horizonte. Belo Horizonte, 2004. 130p. [Dissertação de Mestrado. Faculdade de Farmácia. Universidade Federal de Minas Gerais].

NIMMO, C.M.; HOLLAND, R.W. Transitions in pharmacy practice, part 2: who does what and why. Am. J. Health Syst. Pharm., v.56, n.19, p.1981-1987, 1999.

NORRIS, S.L.; LAU, J; SMITH, S.J; SCHMID, C.H; ENGELGAU, M.M. Self-management education for adults with type 2 diabetes. Diabetes Care, v.25, n.7, p.1159-1171, 2002. 
ORGANIZAÇÃO MUNDIAL DE SAÚDE. Organização PanAmericana De Saúde. Cid-10: Classificação estatística internacional de doenças e problemas relacionados à saúde. 9.ed. São Paulo: Edusp, 2003. 3v.

ORGANIZAÇÃO PAN-AMERICANA DA SAÚDE. Consenso Brasileiro de Atenção Farmacêutica: Proposta, 2002. Brasília (DF), 2002. 23p.

RADHAMANOBAR, M.; THAN, M.; RIZVI, S. Assessment of patient's knowledge about their illness and treatment. Br. $J$. Clin. Pract., v.47, p.23-25, 1993. apud Rev. Saúde Pública, v.35, n.2, p.207-213, 2001.

ROZENFELD, S. Prevalência, fatores associados e mau uso de medicamentos entre os idosos: uma revisão. Cad. Saúde Pública, v.19, n.717-24, 2003.

ROSSINHOLI, P.S.; SOUZA, R.A.P.; SATO, M.N.; CORDEIRO, B.Z.S.; GAMPER, M.C.P. Resultados iniciais da atenção farmacêutica: a experiência da farmácia USIMED. In: CONGRESSO NACIONAL DA REDE UNIDA4, Londrina, 2002. Anais. Londrina: Olho Mágico/ Centro de Ciências da Saúde/UEL, 2002. v.9, p.106-107.

SEGUNDO consenso de Granada sobre problemas relacionados con medicamentos. Ars Pharm., v.43, n.3-4, p.175-184. 2002.
SOCIEDADE BRASILEIRA DE HIPERTENSÃO ARTERIAL. $V$ Diretrizes brasileiras de hipertensão arterial, 2006. Available at: <http://www. publicacoes.cardiol.br/ consenso/2006/VDiretriz-HA.pdf. Access on: 15 mar. 2009.

SOUZA W. A; YUGAR-TOLEDO, J. C; BERGSTENMENDES, G.; SABHA, M; JÚNIOR, H. M. Effect of pharmaceutical care on blood pressure control and healthrelated quality of life in patients with resistant hypertension. Am. J. Hosp. Pharm., v.64, p.1955-1961, 2007.

STRAND, L.M.; MORLEY, P. C.; CIPOLLE, R. J.; RAMSEY, R.; LAMSAM, G. D.. Drug-related problems: their structure and function. Ann. Pharmacother., v.24, p.1093-1097, 1990.

SZWARCWALD, C.L. O Brasil em números. Radis Props. $J$. Reforma Sanit., n.23, p.14-33. 2004.

UNIVERSIDAD DE GRANADA. Grupo de investigación en Atención Farmacéutica. Manual Programa Dáder de Implantación del seguimiento del tratamiento farmacológico, 1999. Granada, 1999. 9 p.

WORLD HEALTH ORGANIZATION. The ATC/DDD System. Available at: http://www.whocc.no/atcddd. Access on: 26 may 2004.

Received for publication on $30^{\text {th }}$ july 2008 Accepted for publication on $10^{\text {th }}$ november 2008 